\title{
The Impact of Using Combine Harvester on Economic Factors of Rice Farmers in Gowa Regency
}

\author{
Rudy Immanuel Pundising ${ }^{1}$, Laode Asrul $^{2}$, Mahyuddin ${ }^{3}$ \\ ${ }^{1}$ Agribusiness Study Program at Postgraduate, Hasanuddin University \\ ${ }^{2}$ Department of Agricultural Socio-Economics, Faculty of Agriculture, Hasanuddin University \\ ${ }^{3}$ Departement of PostGraduated, Hasanuddin University \\ ${ }^{*}$ Corresponding author: \\ Email: rudypundising83@gmail.com
}

\begin{abstract}
.
Efforts from a development process cannot be separated from the existence of effective agricultural information and technology as well as accurate information in the hope that there will be changes in the behaviour and abilities of farmers in farming activities and increased production to realize the goals of a development process, namely rice self-sufficiency. Gowa Regency is a district whose population is mostly engaged in agriculture and areas that do not escape the government's attention, especially in the agricultural sector. In applying new technology, of course, there must be the roles of certain parties in the application of technology, both from the government, extension agents and farmers (target/community). The data needed in this study are primary data and secondary data. Primary data is data obtained directly from the field through direct interviews with sample farmers who are guided by prepared questionnaires. The data obtained are primary and secondary data processed by quantitative methods. In this study, the analysis used is the different test for two different samples (t-test) and the Structural Equation Model (SEM) analysis model. Combine harvester affects the socio-economic income of lowland rice farmers in Gowa Regency with the presence of agricultural machine tools combine harvester, so rice farmers are more benefited from a time-efficient point of view and the need for labour was minimal and income also increased by about 15\% from conventional harvesting. There is a need for socialization of the use and utilization of agricultural so that farmers are more interested in using agricultural machine tools in the field.
\end{abstract}

Keywords: Bivalvia, bray-curtis, cannonical correspondence analysis, density, gastropoda.

\section{INTRODUCTION}

Until now, the agricultural sector still has a very important role in national development as well as supporting the nation's economy. Efforts in a development process cannot be separated from the existence of effective agricultural information and technology as well as accurate information in the hope that there will be changes in the behaviour and abilities of farmers in farming activities and increased production to realize the goals of a farm. the development process is rice self-sufficiency [1].

[2]stated that the "development" of society is a multi-dimensional structural process that includes all aspects of society, but initially necessary, especially

http://ijstm.inarah.co.id 
economic development. A form of change is not only in terms of physical form, but change can also be related to the form of the program. The program in question is a program implemented at the individual, family, group and community level as an empowerment effort (fostering farmers from disabilities to empowerment), to achieve a better life [3]. [4] define empowerment as the process by which people become strong enough to participate in various controls over various programs and influence events and institutions that affect their lives. The main approach in the concept of empowerment is that farmers are not the object of various development projects, but the subject of development efforts.

In economics what is meant by labour is a means of physical strength and the human brain that cannot be measured from humans and runs a production business [5]. Farmers are people who work directly or indirectly or from time to time in farming and other activities related to the life and livelihoods of rural farmer families [6]. Human labour is divided into male, female and child labour. If the age is relatively young, it will be faster to complete the work than the relatively old age. On the other hand, workers who are relatively old are more experienced so that they are more skilled at completing work than those who are less experienced. Education will influence, think and work [7]. Farmers and families are the targets of agricultural extension workers whose behaviour must be changed in farming and farming practices to increase farmers' production and income.

\begin{tabular}{ll} 
Umur Petani & Variabel \\
\hline $0-14$ Tahun & Belum Produktif \\
$15-64$ Tahun & Produktif \\
65 Tahun Keatas & Tidak Produktif \\
\hline Sumber: Badan Pusat Statistik 2015 &
\end{tabular}

[8] The combined harvester is a rice harvester technology that was first developed in South Korea and Japan. Combined harvester is basically a rice harvester that helps farmers in harvesting rice. This technology is very helpful in terms of labour, time, harvest costs and harvest speed. The rice harvesting process using a combination harvester is very helpful for farmers in harvesting rice, which can increase the time speed by up to $75 \%$ compared to using human labour. In the last period of time, the use of agricultural machine tools in agriculture has grown to overcome the limited workforce in rural areas. The working capacity of the combined harvester itself is 5.05 hours/ha. [9]. 


\section{METHODS}

This research will be conducted in Gowa Regency. The location of this study was determined on purpose with the consideration that Gowa Regency is one of the districts that has implemented an empowerment program for the use of a combine harvester to increase lowland rice production. This research will be carried out from October to November 2019.

The data needed in this study are primary data and secondary data. Primary data is data obtained directly from field interviews with sample farmers who are guided through a prepared questionnaire. Meanwhile, secondary data is supporting data from related institutions in this research, research results, scientific magazines, journals and literature studies related to this research. The data technique used by the researcher was structured interviews with farmers guided by a questionnaire that had been prepared and direct observation of the research location.

The data obtained are primary and secondary data processed by quantitative methods. In this study, the analysis that will be used is the different test for two different samples (t-test) and the Structural Equation Model (SEM) analysis model. The difference test is used to see if there is a significant difference in the income of farmers before using the combine harvester and farmers after using the combine harvester.

$$
\begin{gathered}
\sigma^{2}=\frac{\left(n_{1}-1\right) s 1^{2}+\left(n_{2}-1\right) s 2^{2}}{n_{1}+n_{2}-2} \\
\sigma x 1-x 2=\sqrt{\frac{\sigma^{2}}{n_{1}}+\frac{\sigma^{2}}{n_{2}}} \\
\mathrm{t}=\frac{x 1-x 2}{\sigma X 1-\sigma X 2}
\end{gathered}
$$

Descriptive analysis is an analysis that describes systematically, accurate facts and characteristics about the population/ activities carried out in certain fields that make research subjects based on data from variables obtained from the group of subjects under study and facts that occur in the field.

\section{RESULT AND DISCUSSION}

The Combine Harvester is a complex agricultural machinery in various postharvest uses over a very large area of land. Actually, to increase the productivity of agricultural products, people should see a role. important from the application of this tool, which is very profitable from an economic point of view. The existence of the combine harvester makes it easier for farmers in the harvesting process and can also 
cut transmission costs at harvest. The following is a comparison before using the combine harvester and after using the combine harvester.

Source: Primary Data After Processing, 2019

With the Combine Harvester, the harvest time becomes more efficient so that the harvest schedule and to replant can be faster and easier. If you look at the table below, which is the estimated time used by farmers before and after using the Combine Harvester, it is very clear, here is a table that shows the efficiency of harvesting using conventional methods and after using the Combine Harvester technology.

\begin{tabular}{|l|l|l|l|}
\hline No & Farmers & $\begin{array}{l}\text { harvest process before } \\
\text { using the combine } \\
\text { harvester }\end{array}$ & $\begin{array}{l}\text { harvest process } \\
\text { after using the } \\
\text { combine harvester }\end{array}$ \\
\hline 1 & Lego Romangloe & 81,5 day & 53 hour \\
\hline 2 & Baji' Pa'mai & 87,5 day & 50,5 hour \\
\hline 3 & Salaku Romangloe & 62,5 day & 36,5 hour \\
\hline 4 & Tamalayu Pallantikang & 99 day & 62 hour \\
\hline 5 & Teamate Jaya Pallantikang & 63,5 day & 45 hour \\
\hline & Total & $\mathbf{3 9 4}$ day & $\mathbf{2 4 7}$ hours \\
\hline
\end{tabular}

Source: Primary Data After Processing, 2019

By facilitating farmers with the Combine Harvester machine that can speed up the harvesting process, it can automatically influence the opinions of farmers, which can be said to greatly influence opinions from before using conventional methods or using the Combine Harvester, the table below will show that the comparison of income farmers before and after using the Combine Harvester as follows:

\begin{tabular}{|l|l|l|l|}
\hline No & Farmers & $\begin{array}{l}\text { Farmers' Net Income } \\
\text { Before using Combine }\end{array}$ & $\begin{array}{l}\text { Farmers' Net Income } \\
\text { after using Combine }\end{array}$ \\
\hline 1 & Lego Romangloe & Rp450.000.000 & Rp499.100.000 \\
\hline 2 & Baji' Pa'mai & Rp404.400.000 & Rp449.333.333 \\
\hline 3 & Salaku Romangloe & Rp246.000.000 & Rp283.333.333 \\
\hline 4 & Tamalayu Pallantikang & Rp486.000.000 & Rp541.333.333 \\
\hline 5 & $\begin{array}{l}\text { Teamate Jaya } \\
\text { Pallantikang }\end{array}$ & Rp364.200.000 & Rp404.333.333 \\
\hline & Total & Rp1.950.600.000 & Rp2.177.433.332 \\
\hline
\end{tabular}

Source: Primary Data After Processing, 2019

\section{The Results Of The Research Analysis Using The T Test}

From the results that have been obtained when carrying out research in the field and carrying out the processing, it is necessary to obtain the results needed. 
The Results Of Spss For Farmers Net Income Before And After Using A Combination Of 5 Farmer Groups

\begin{tabular}{|c|c|c|c|c|c|}
\hline & & Mean & $\mathrm{N}$ & Std. Deviation & Std. Error Mean \\
\hline Pair 1 & $\begin{array}{l}\text { sebelum } \\
\text { sesudah }\end{array}$ & $\begin{array}{c}3.90 \mathrm{E} 8 \\
4.35 \mathrm{E} 8\end{array}$ & $\begin{array}{l}5 \\
5\end{array}$ & $\begin{array}{l}9.277 \mathrm{E} 7 \\
9.945 \mathrm{E} 7\end{array}$ & $\begin{array}{l}4.149 E 7 \\
4.448 E 7\end{array}$ \\
\hline
\end{tabular}

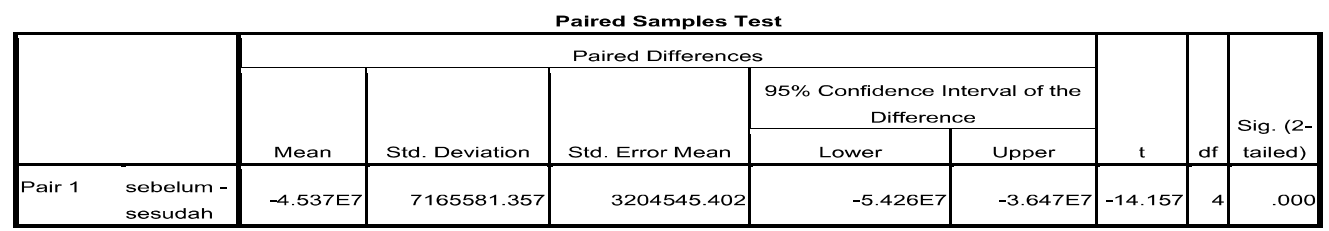

Source: Primary Data After Processing, 2019

\section{SPSS Results For Rice Harvest Costs Before And After Combining 5 Farmer Groups}

Paired Samples Statistics

\begin{tabular}{|rr|r|r|r|r|}
\hline & & Mean & $\mathrm{N}$ & Std. Deviation & Std. Error Mean \\
\hline Pair 1 & sebelum & $9.73 \mathrm{E} 7$ & 5 & $2.252 \mathrm{E} 7$ & $1.007 \mathrm{E} 7$ \\
& sesudah & $5.38 \mathrm{E} 7$ & 5 & $1.220 \mathrm{E} 7$ & 5454952.747 \\
\hline
\end{tabular}

Paired Samples Statistics

\begin{tabular}{|rr|r|r|r|r|}
\hline & \multicolumn{1}{|c|}{ Mean } & $\mathrm{N}$ & \multicolumn{1}{c|}{ Std. Deviation } & Std. Error Mean \\
\hline Pair 1 & sebelum & $7.88000 E 1$ & 5 & 15.738488 & 7.038466 \\
& sesudah & 2.05800 & 5 & .394707 & .176518 \\
\hline
\end{tabular}

Source: Primary Data After Processing, 2019

Source: Primary Data After Processing, 2019

red Samples Test

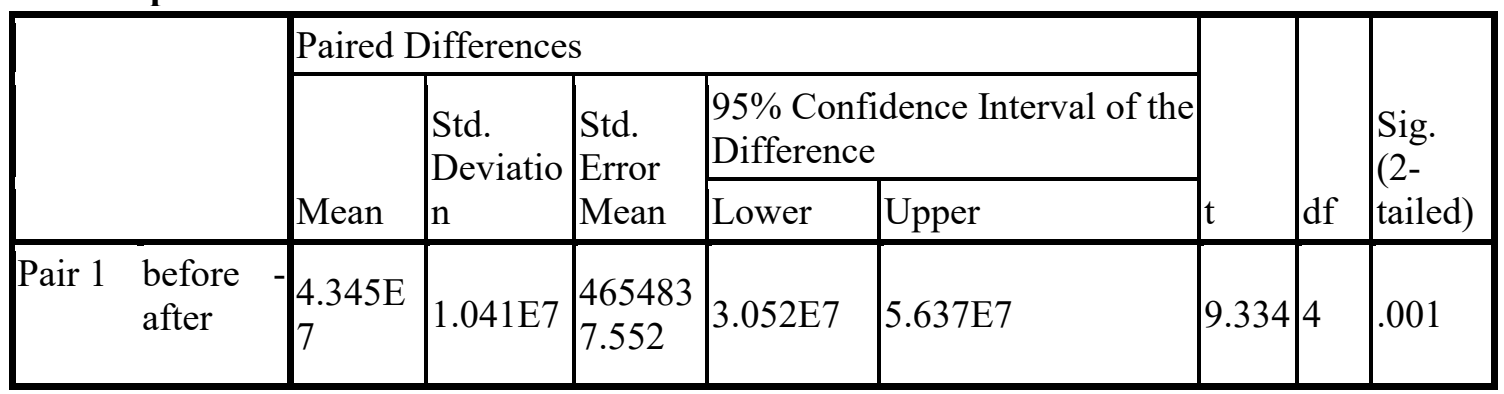

Harvest Time Before and After Using Combine 5 Groups

Source: Primary Data After Processing, 2019 
Paired Samples Test

\begin{tabular}{|c|c|c|c|c|c|c|c|c|c|}
\hline & & \multicolumn{5}{|c|}{ Paired Differences } & \multirow[b]{3}{*}{$\mathrm{t}$} & \multirow[b]{3}{*}{ df } & \multirow{3}{*}{$\begin{array}{l}\text { Sig } \\
(2- \\
\text { tail } \\
\text { ed })\end{array}$} \\
\hline & & \multirow[b]{2}{*}{ Mean } & \multirow{2}{*}{$\begin{array}{l}\text { Std. } \\
\text { Deviation }\end{array}$} & \multirow{2}{*}{$\begin{array}{l}\text { Std. Error } \\
\text { Mean }\end{array}$} & $\begin{array}{l}95 \% \\
\text { Interval } \\
\text { Difference } \\
\end{array}$ & $\begin{array}{c}\text { Confidence } \\
\text { of the }\end{array}$ & & & \\
\hline & & & & & Lower & Upper & & & \\
\hline Pair 1 & $\begin{array}{l}\text { Before- } \\
\text { after }\end{array}$ & $\begin{array}{l}7.67420 \\
0 \mathrm{E} 1\end{array}$ & 15.374201 & 6.875552 & 57.652409 & $\begin{array}{l}95.83159 \\
1\end{array}$ & 11.162 & 4 & $\begin{array}{l}.00 \\
0\end{array}$ \\
\hline
\end{tabular}

Source: Primary Data After Processing, 2019

The use of labour at harvest before and after using combine 5 farmer groups

Paired Samples Statistics

\begin{tabular}{|rr|r|r|r|r|}
\hline & Mean & $\mathrm{N}$ & Std. Deviation & Std. Error Mean \\
\hline Pair 1 & sebelum & 140.80 & 5 & 2.950 & 1.319 \\
& sesudah & 64.00 & 5 & 6.519 & 2.915 \\
\hline
\end{tabular}

Paired Samples Correlations

\begin{tabular}{|l|r|r|r|}
\hline & $\mathrm{N}$ & Correlation & \multicolumn{1}{c|}{ Sig. } \\
\hline Pair 1 sebelum \& sesudah & 5 & -.533 & .355 \\
\hline
\end{tabular}

Source: Primary Data After Processing, 2019

\section{Paired Samples Test}

\begin{tabular}{|c|c|c|c|c|c|c|c|c|c|}
\hline & & \multicolumn{5}{|c|}{ Paired Differences } & \multirow[b]{3}{*}{$\mathrm{t}$} & \multirow[b]{3}{*}{ df } & \multirow{3}{*}{$\begin{array}{l}\text { Sig. } \quad(2- \\
\text { tailed })\end{array}$} \\
\hline & & \multirow[b]{2}{*}{ Mean } & \multirow{2}{*}{$\begin{array}{l}\text { Std. } \\
\text { Deviatio } \\
\text { n }\end{array}$} & \multirow{2}{*}{\begin{tabular}{|l} 
Std. \\
Error \\
Mean
\end{tabular}} & \multicolumn{2}{|c|}{$\begin{array}{l}95 \% \text { Confidence Interval } \\
\text { of the Difference }\end{array}$} & & & \\
\hline & & & & & Lower & Upper & & & \\
\hline $\begin{array}{l}\text { Pair } \\
1\end{array}$ & $\begin{array}{l}\text { Before- } \\
\text { after }\end{array}$ & $\mid \begin{array}{l}76.80 \\
0\end{array}$ & 8.468 & 3.787 & 66.286 & 87.314 & 20.281 & 4 & .000 \\
\hline
\end{tabular}

Source: Primary Data After Processing, 2019

\section{CONCLUSION}

Combine harvester has an effect on the socio-economic income of lowland rice farmers in Gowa Regency with the existence of the agricultural machine tools combine harvester so that rice farmers benefit more from a time efficiency perspective and also fewer labour needs and income increases by about $15 \%$ from conventional harvesting. Lowland rice farmers to use a combine harvester in Gowa Regency are efficient in 
terms of time, labour and farmer net income has increased. The utilization of Alsintan that is given by the government to farmers must be utilized as well as possible by the farmers, so that the farmers will find it easier in the farming process, starting from land processing to harvesting so that it can save time and maintenance costs can also be reduced. There is a need for socialization of the use and utilization of agricultural machinery so that farmers are more interested in using agricultural machine tools in the field.

\section{ACKNOWLEDGMENTS}

The authors are grateful to Hasanuddin University, to the Agribusiness Study Program at Postgraduate, and to the Department of Agricultural Socio-Economics. We also thank Team author for your good cooperation.

\section{REFERENCES}

[1] Soetriono Dan Anik. 2016. Pengantar Ilmu Pertanian. Intimedia. Malang.

[2] Jansen. P.1970.Teknik-teknik Pengembangan Masyarakat. Institut Pengembangan Masyarakat Malang, 173. Malang.

[3] Rukminto. 2003. Pemberdayaan Pembangunan Masyarakat dan Interfensi Komunitas. Jakarta: Fakultas Ekonomi Universitas Indonesia.

[4] Suharto. 2005. Membangun Masyarakat Memberdayakan Rakyat. PT. Rivika Adilama. Bandung.

[5] Daniel, M. 2004. Pengantar Ekonomi Pertanian. Bumi Aksara. Jakarta.

[6] Muchlis, F. 2009. Analisis Komunikasi Partisipatif Dalam Program. Pemberdayaan Masyarakat. Institut Pertanian Bogor. Bogor. Mubyarto. 1989. Pengantar Ekonomi Pertanian. LP3ES. Jakarta.

[7] Hernanto. 1993. Ilmu Usaha Tani. Penebar Swadaya.Jakarta.1996. Ilmu Usahatani. Penebar Swadaya. Jakarta

[8] Badan Pusat Statistik. 2015. http://bps.go.id.

[9] Indro, P. 1992. Mesin Perontok Padi. Kanisius. Yogyakarta. 